JOLANTA WASILEWSKA* - LUBLIN

\title{
TATUAŻ JAKO ZNAK PRZYNALEŻNOŚCI
}

Słowo tatuaż pochodzi od polinezyjskiego tatu co oznacza znak, pismo, malowidło, którego rdzeń ta określa czynność bicia, stukania, rycia. Do Europy dotarł dzięki angielskiemu podróżnikowi Jamesowi $\operatorname{Cook}^{1} \mathrm{w} 1773$ r. zapisany jako ta$t_{\text {tow }}{ }^{2}$. Zanim w Europie termin tatuaż się upowszechnił, ludzi tak ozdobionych nazywano umalowanymi lub wykropkowanymi, a w odniesieniu do tatuażu używano takich określeń jak: znamię, piętno, rysunek, grafizm, hieroglif, signum, stigma, piquage ${ }^{3}$. Holendrzy czynność tatuowania nazywali prikschilderen czyli malowanie przez nakłuwanie, podobnie Anglicy (punctures) i Hiszpanie (pintados). $\mathrm{Z}$ czasem termin tatuaż przyjął się praktycznie w całej Europie ${ }^{4}$.

\section{Znaczenie}

W dziejach ludzkości tatuaż jest jedna z najstarszych form dekorowania ciała i niesie specyficzne znaczenie, wyrażające się przez wywołanie określonego efektu plastycznego podobnego do zwyczaju malowania ciała. Pierwotnym znaczeniem tatuażu były obrzędy rytualne. Zadania jakie miał spełniać tatuaż były bardzo różnorodne, od potrzeby upiększania ciała, zaznaczenia pozycji społecznej lub rodzinnej, przynależności do grupy kulturowo-etnicznej, religijnej czy za-

* Jolanta Wasilewska - mgr historii sztuki; starszy kustosz dyplomowany w Bibliotece Uniwersyteckiej KUL; e-mail: jolanta.wasilewska@kul.pl

${ }^{1}$ James Cook (1728-1819) - angielski żeglarz i odkrywca, kartograf, astronom. Organizator i kierownik trzech wypraw dookoła świata w latach 1768-1779.

${ }^{2}$ "Cooka uważa się za osobę, która nadała angielskiemu słowu tattoo jego dzisiejsze znaczenie”. T. Russ, Sztuka tatuażu: inspiracje, style i techniki wielkich współczesnych mistrzów tatuażu, Warszawa 2014, s. 19; A. Jelski, Tatuaż, Warszawa 1993, s. 24.

${ }^{3}$ S. Wargacki, Tatuaż, w: Encyklopedia Katolicka (dalej: EK), t. 19, Lublin 2013, kol. 552-553.

${ }^{4} \mathrm{~W}$ jęz. ang. - tattoo, jęz. niem. - Tätowierung, jęz. wł. - tatuaggio, jęz. hiszp. - tatuaje. W jęz. polskim tatuaż jest zapisem fonetycznym francuskiego słowa tatouage. 
wodowej do funkcji leczniczych czy też do upamiętnienia czynów bohaterskich ${ }^{5}$. Stosowany był także do celów magicznych, rytualnych i seksualnych ${ }^{6}$. Wreszcie był znakiem identyfikacyjnym, piętnującym niewolników, zbiegów, jeńców i więźniów, rozprzestrzeniał się także w środowiskach przestępczych. Zwyczaj tatuowania przetrwał do obecnych czasów szczególnie w środowisku marynarzy, artystów i wśród grup kontestacyjnych (w subkulturach), a zwłaszcza wśród młodzieży.

\section{Techniki wykonania tatuażu}

W zależności od położenia geograficznego, możliwości materiałowych i narzędzi, czasu, rozwoju cywilizacyjnego i tradycji, funkcjonowały różne techniki wykonania tatuażu.

Można wyróżnić trzy główne techniki tatuażu. Najstarsza technika, współcześnie rzadko spotykana, polega na drapaniu skóry ostrym narzędziem (zaostrzona kość, rybi ząb), po śladach wcześniej naniesionego rysunku. Następnie w naciętą powierzchnię skóry wcierano barwnik; po wygojeniu zadrapań na skórze pozostawał trwały rysunek. Wydrapywanie stosowały niektóre plemiona Indian ${ }^{7}$ Ameryki Południowej na terenach Mato Grosso i wywodziło się od zwyczajowego malowania ciała ${ }^{8}$.

Druga stara technika, zasadniczo odmienna od pierwszej, polegała na użyciu igły (z twardego drewna, kości lub ości) i nici (ze ścięgna zwierzęcego), które moczono w naturalnych barwnikach (sadza, grafit) wymieszanych z thuszczem. Tak zabarwioną nić za pomocą igły przeciągano pod skórą wzdłuż linii wcześniej naniesionego wzoru. Ta prosta, mało skomplikowana technika znana była ludom na obszarach północno-wschodniej Syberii (m.in. u Czukczów, Ewenków, Jakutów, Ostiaków i Tunguzów) oraz wśród Eskimosów w Ameryce Północnej9. Dwie pierwsze metody są już dzisiaj przeżytkiem kulturowym o ograniczonym zasięgu występowania.

Trzeci sposób wykonania tatuażu, najpopularniejszy, polega na punktowym nakłuwaniu skóry kolcem z twardego drzewa (ptasiej kostki, rybiej ości, lub odłamkiem muszli), który uderzano kamieniem, a następnie wcierano barwnik

${ }^{5} \mathrm{~W}$ wielu kulturach mogli sobie pozwolić nań jedynie nieliczni - najczęściej plemienni wojownicy. Tego typu ozdoby były szczególnie rozpowszechnione w kulturach polinezyjskich, gdzie do wykonania tatuażu uprawniało dopiero zabicie wroga i zdobycie jego (wytatuowanej) głowy. https://pl.wikipedia.org/wiki/Tatua\%C5\%BC (dostęp: 30.03.2017).

${ }^{6}$ „Tatuaż w swej prahistorii stanowił element rytuału i dlatego był częścią pogańskiej symboliki. Prawie u wszystkich ludów pierwotnych to część kultu bogów - demonów praktykowany podczas świąt im poświęconych, przez szamanów, magów, rytów”. A. Zwoliński, Mowa ciała, Kraków 2006, s. 38.

${ }^{7}$ Indianie drapali skórę cierniami z roślin i wcierali sadzę lub sok z jagód. M. Delio, Tatuaż, Warszawa 1995, s. 65.

${ }^{8}$ Jelski, Tatuaż, s. 16-20.

${ }^{9}$ M. Skopek, Tatuaż: element współczesnej kultury, Toruń 2013, s. 36; L. Pietrzak, Tatuaż jako sztuka wizualna-Tattoo as visual art-Tattoo als visuelle Kunst, Poznań 2013 http://leszekpietrzak. com/assets/files/uberink-historia-tatuazu.pdf (dostęp: 14.03.2017) 
wzdłuż konturów lub w wyznaczonych płaszczyznach. Do wykonywania większych powierzchni posługiwano się przyrządem podobnym do grzebyka. W kawałek drewienka (kości) nabijano rząd ostrych szpikulców z kości, muszli lub kamyków; tak przygotowanym narzędziem nakłuwano skórę ${ }^{10}$. Metoda ta znana była na wyspach Oceanii, a zwłaszcza Polinezji i na odległych wyspach takich jak Hawaje i Wyspa Wielkanocna ${ }^{11}$, Nowej Zelandii, a także ludom Południowo i Północno-Wschodniej Azji, Chin i Japonii, Indonezji, Afryki i obu Ameryk ${ }^{12}$.

Oprócz tatuażu zamierzonego, dobrowolnego lub przymusowego należy odróżnić od tatuażu przypadkowego i bliznowego. Tatuaż przypadkowy może powstać w następstwie urazu i wniknięcia do skóry cząstek węgla, żużlu, pyłu lub w wyniku eksplozji pocisków, min itp. ${ }^{13}$, natomiast bliznowy (skaryfikacja, cykartyzacja) powstaje poprzez wielokrotne nacięcie skóry za pomocą ostrego narzędzia takiego jak w ostro zakończony kawałek bambusa, muszli, noża, brzytwy czy żyletki. Zabieg ten powtarza się wielokrotnie nie dopuszczając do całkowitego zabliźnienia rany, tym sposobem tworzą się trwałe blizny, szramy tworząc rozległe wzory ${ }^{14}$.

\section{Historia tatuażu \\ Czasy najdawniejsze}

Ustalenie konkretnego czasu i miejsca dla początku zjawiska tatuażu nie jest możliwe, chociaż wiele badań wskazuje, że sztuka zdobienia skóry istnieje od ponad 8000 lat $^{15}$.

W licznych jaskiniach odnajdowano ostro zakończone narzędzia w kształcie igieł, na których widoczne były ślady czarnego i czerwonego pigmentu ${ }^{16}$. Na podstawie znalezisk archeologicznych i badań różnego rodzaju artefaktów można zatem przypuszczać, że tatuowanie znane było już ludom pierwotnym. Odnalezione figurki na terenach Węgier i Rumunii, datowane na okres neolitu (ok. 4 000-1 700 lat p.n.e.), ukazują ozdobne znaki, często w formie geometrycznych i zoomorficznych wzorów. Ornamenty te najczęściej w formie kresek, kropek lub rombów

${ }^{10}$ Grzebyki były różnej wielkości, większe służyły do nakłuwania dłuższych linii przy większych fragmentach rysunków, małe do drobnych elementów. L. Mróz, Tatuaż, „Poznaj Świat”, 12 (1969) s. 29.

${ }^{11}$ Tamże, s. 27.

${ }^{12}$ Russ, Sztuka tatuażu: inspiracje, style i techniki wielkich wspótczesnych mistrzów tatuażu, s. 16.

${ }^{13}$ K. Lejman, Tatuaż dawniej i dziś, jako zagadnienie obyczajowe, psychologiczne i lekarskie, „Archiwum Historii Medycyny”, 29 (1966) s. 95.

${ }^{14}$ J. Kukuczka, Afrykańskie tatuaże bliznowe, „Ludzie i Kultury”, 1 (2003) s. 34.

${ }^{15}$ R. Nowak, Psychologiczne aspekty tatuowania się, „Roczniki Psychologiczne”, 15 (2012) nr 2, s. 88.

${ }^{16} \mathrm{~W}$ jaskiniach we Francji, Portugalii, Rumunii czy Skandynawii odnaleziono narzędzia, ostro zakończone krzemienie i igły sporządzone z odłamków kości zwierząt, służące do wykonywania trwałych znaków na skórze. Snopek, Tatuaż. Element wspótczesnej kultury, s. 19. 
pokrywają barki, piersi, pośladki i uda ${ }^{17}$. Najstarszym udokumentowanym zabytkiem tatuażu $\mathrm{z}$ tej epoki jest odnalezione w alpejskim lodowcu ciało człowieka, nazwanego Ötzi ${ }^{18}$. Jego dobrze zachowana skóra pokryta jest 61 tatuażami ${ }^{19}$.

Na ok. 4000 lat szacuje się wiek mumii Amunet, tebańskiej kapłanki bogini Hathor odnalezionej w Egipcie, która była ozdobiona tatuażami w formie linii i serii kropek umiejscowionymi na brzuchu ${ }^{20} . Z$ tego samego okresu (ok. 2050 ok. 1760 p.n.e.) pochodzą kawałki ludzkiej skóry wytatuowanej w romby, odnalezione na jednym z cmentarzysk $\mathrm{z}$ terenów Nubii. W grobowcu faraona Seti I (ok. 1300 p.n.e.) odnaleziono malowidła przedstawiające postaci mężczyzn, których nogi i ręce ozdobione są różnymi ornamentami. Przypuszcza się z dużą dozą pewności, że Egipcjanie tatuowali tylko konkretne grupy kobiet: śpiewaczki, tancerki, konkubiny. Natomiast wśród mężczyzn tatuowanie ograniczało się jedynie do przedstawicieli obcych ras oraz więźniów ${ }^{21}$.

\section{Miejsce i czas}

\section{Wyspy Oceanii}

W Polinezji i Mikronezji tatuaż związany był przede wszystkich z obrzędem inicjacji, dojrzewania. Po przejściu pewnych prób i ceremonii, dziewczęta i chłopcy stawali się pełnoprawnymi członkami społeczności i mogli już zakładać rodzinę. Tatuaż polinezyjski opierał się głównie na wzorach geometrycznych, spiralach, meandrach i liniach falistych. Miał on znaczenie zarówno religijne, hierarchiczne, jak i symboliczne. Tatuaż miał istotne znaczenie w rytuałach i tradycji. Tatuaż wokół nadgarstków lub palców miał odpędzać choroby. Pełnił on funkcję ochronną (np. przed dzikimi zwierzętami, duchami), jak również informacyjną (np. o pozycji w społeczności) ${ }^{22}$. W zależności od wyspy miał wiele odmian lokalnych wyróżniających się cechami stylistycznymi, kompozycją, różnorodno-

${ }^{17}$ Nie można całkowicie stwierdzić, że znaleziska te przedstawiały odniesienie do zwyczaju tatuowania czy tylko do malowania ciała, jednak mogły być przyczynkiem do tworzenia tatuażu. Jelski, Tatuaż, s. 30; M. Delio, Tatuaż: Egzotyczna sztuka dekorowania skóry, Warszawa 1995, s. 64.

${ }^{18}$ Ötzi, Człowiek Lodu - przydomek nadany szczątkom człowieka, który zmarł ok. 3300 lat p.n.e. Przydomek ten pochodzi od nazwy doliny Ötztal w Południowym Tyrolu, w Alpach Ötztalskich, ponad którą znaleziono jego zamrożone w lodowcu alpejskim ciało. Znaleziony został na wysokości 3210 m n.p.m. przez dwoje niemieckich turystów, 19 września 1991 roku. https://pl.wikipedia.org/wiki/\%C3\%96tzi (dostęp: 20.03.2017)

${ }^{19}$ Ötzi miał w sumie 61 tatuaży, składających się z 19 grup czarnych linii o grubości od 1 do $3 \mathrm{~mm}$ i długości 7 do $40 \mathrm{~mm}$. Obejmują one grupy równoległych linii biegnących wzdłuż osi wzdłużnej jego ciała i obu stron kręgosłupa lędźwiowego, a także znaku krzyżowego za prawym kolanem i prawej kostki oraz równoległymi liniami wokół lewego nadgarstka. Najwięcej znaków znajduje się na nogach, aż 12 grup linii. Mikroskopowe badanie próbek zebranych z tych tatuażów wykazało, że powstały one z pigmentu wyprodukowanego z popiołu lub sadzy. https://en.wikipedia. org/wiki/\%C3\%96tzi (dostęp: 20.03.2017)

${ }^{20}$ Snopek, Tatuaż, s. 19.

${ }^{21}$ Raport końcowy, Modyfikacja tatuaże, Łódź 2011, s. 3. http://www.eksoc.uni.lodz.pl/is/doc/ tatoo.pdf (dostęp: 30.03.2017)

${ }^{22} \mathrm{http}: / /$ renatazarzycka.pl/2011/04/tatuaz-dobry-czy-zly-obyczaj/ (dostęp: 30.03.2017) 
ścią motywów geometrycznych, linearnych, roślinnych, antropomorficznych i zoomorficznych ${ }^{23}$. Na licznych wyspach tatuowanie nie ograniczało się tylko do obrzędu inicjacji, było kontynuowane przez całe życie, zapełniając wzorami całe ciało, opowiadając historię danej osoby. Na niektórych wyspach tatuuje się tylko kobiety (wyspy Fidżi), a na innych mężczyzn (Samoa). Na wyspie Samoa początkowo wzory były ułożone z szeregów linii i punktów, przypominając zygzaki, kąty, fale, trójkąty, dopiero później ornamenty stały się bardziej zróżnicowane i plastyczne osiągając pełny rozkwit na przełomie XVIII i XIX wieku. Tatuowano nie tylko tułów, ręce i nogi, ale wszystkie palce, całą twarz, głowę (po ogoleniu), a nawet język ${ }^{24}$. Ciało pokryte wzorami, informowało o pozycji w danej społeczności, dodawało prestiżu, świadczyło o czynach i przynależności do rodu (plemienia, szczepu), jednocześnie spełniał funkcję dekoracyjną i symboliczną ${ }^{25}$. Wyjątkowymi i niebywale ekspresyjnymi wzorami tatuowali twarze Maorysi w Nowej Zelandii. Wzory te nosiły nazwę moko lub amoka (jaszczurka) ${ }^{26}$. Wykonywano go specjalnym bardzo ostrym narzędziem (ostro zakończoną kością, drzazgą z twardego drzewa albo zębem rekina), nacinając płytkie rowki, w które wcierano barwnik ${ }^{27}$. Zwyczaj moko był oznaką pozycji społecznej, a ze względu na koszt wykonania był dostępny tylko dla wodzów plemiennych i zasłużonych wojowników. Zasadniczo prawo do moko posiadali wyłącznie mężczyźni, chociaż z czasem kobiety zaczęły tatuować okolice ust i brody (tych tatuaży jednak nie nazywano moko ${ }^{28}$. Na Wyspie Wielkanocnej najczęściej tatuowano motyw żółwia, ptaka czy łodzi, a na Hawajach tatuaż oprócz znaków identyfikacyjnych, ochronnych czy magicznych spełniał jeszcze jedną funkcję - żałobną ${ }^{29}$.

\section{Kontynent amerykański}

Tatuaż w Ameryce Środkowej i Południowej (tereny dzisiejszej Kolumbii, Ekwadoru i Peru) znany był w wielu kulturach prekolumbijskich ${ }^{30}$. Niezwykle ciekawe wzory spotkać można w kulturze Moche (Peru). Najczęściej spotyka-

${ }^{23}$ Jelski, Tatuaż, s. 104.

${ }^{24}$ Mróz, Tatuaż, s. 27.

${ }^{25}$ P. Szuppe, Tatuaż w prehistorii, starożytności i kulturach plemiennych, „Nurt SVD”, 43 (2009) z. 2, s. 206.

${ }^{26}$ Moko stanowi odbicie plemiennego charakteru, znak scalający dany ród, dokładnie odtwarzany i przechodzący z ojca na syna powtarzając ten sam wzór. Jelski, Tatuaż, s. 20; Skopek, Tatuaż, s. 36.

${ }^{27}$ Najpiękniejsze i o wysokim kunszcie artystycznym tatuaże wykonywano w Nowej Zelandii. W żadnym miejscu na świecie nie spotka się tatuażu o podobnym charakterze. Mróz, Tatuaż, s. 29; Szuppe, Tatuaż w prehistorii, starożytności i kulturach plemiennych, s. 207.

${ }^{28}$ https://pl.wikipedia.org/wiki/Moko (dostęp: 30.03.2017)

${ }^{29}$ Tatuaż żałobny, czasami połączony ze skaryfikacją, goleniem głowy i ucinaniem palców, stosowany był najczęściej na Hawajach, gdzie ozdabiano nawet język. Mróz, Tatuaż, s. 27.

${ }^{30}$ Świadectwami potwierdzającymi ten stan rzeczy są niezwykle liczne źródła ikonograficzne, ale również resztki pigmentów i ślady tatuaży odkrywane na mumiach”. J. Wołoszyn, Skartfikacja, tatuaż i malowanie twarzy w kulturze Moche - propozycja typologii dla „naczyń portretowych”, „Światowit”, 4 (2002) s. 219. 
nymi wzorami były krzyże, rzędy równoległych linii i motyw kraty naniesione na skórę twarzy - na policzki, okolice ust, oczu, nosa i czoła, natomiast bardziej skomplikowane wzory geometryczne czy zoomorficzne często pokrywały cała jej powierzchnię. W zadrapane lub nacięte ranki wcierano sok roślinny lub popiół.

Majowie zdobili twarze $\mathrm{z}$ okazji zawarcia małżeństwa, ale przede wszystkim tatuaż świadczył o zajmowanej pozycji i przynależności plemiennej oraz pełnił funkcję magiczną i leczniczą. W Ameryce Północnej niektóre plemiona Indian i Eskimosów (ze środkowej części terytorium) stosowały tatuaż nakłuwany, natomiast Eskimosi z części wschodniej i zachodniej tatuowali się za pomocą barwionej nici przeciąganej pod skórą ${ }^{31}$.

\section{Azja}

Na terenach Azji Południowo-Wschodniej i Wschodniej tatuaż najczęściej stanowił ochronę przed chorobami duszy i ciała. U mężczyzn często był oznaką dojrzałości i gotowości bojowej i podobnie jak u kobiet wiązał się z obrzędami inicjacji. Oprócz ornamentów składających się z kresek, kropek i spirali, wykonywano stylizowane formy postaci ludzi i zwierząt. Wzory nanoszono metodą nakłuwania zaostrzonymi narzędziami, a następnie w rany wcierano barwnik. Tradycja tatuowania w Azji Południowo-Wschodniej jest jedną z najstarszych na świecie; znana była szczególnie ludom z terenów dzisiejszej Birmy, Laosu, Tajlandii, na wyspach Borneo, Celebesie, Jawie, Sumatrze, Timorze i innych.

U niektórych plemion tatuowali się tylko mężczyźni, a u innych kobiety, gdzieniegdzie obie płcie. Nie wszyscy też ozdabiali całe ciała, także ornamentyka różniła się: od bardzo prostych geometrycznych wzorów po skomplikowane formy przypominające arabeski, stylizowane smoki i ptaki ${ }^{32}$.

Wyjątkowe znaczenie w życiu społeczno-obyczajowym zajmował tatuaż w Japonii, który rozwinął się na wyspach około 500 lat p.n.e. ${ }^{33}$. Początkowo tatuowano przestępców za karę lub też jako ich znak rozpoznawczy ${ }^{34}$. Oprócz prze-

${ }^{31}$ Lejman, Tatuaż dawniej i dziś, s. 98; Mróz, Tatuaż, s. 30; Szuppe, Tatuaż w prehistorii, starożytności i kulturach plemiennych, s. 207.

${ }^{32}$ Mróz, Tatuaż, s. 29.

${ }^{33}$ Dowodem jest otwarty w 1977 roku grobowiec, z którego wydobyto figurki hanniwa. Noszą one ślady, które wskazują na to, że istniał zwyczaj tatuowania wśród przodków Japończyków. Kolejnym ważnym dowodem na to mogą być zapiski w Wei Chih, czyli kronikach Wei, oraz San Kuo Chi (dzieje trzech królestw), w których zawarte są informacje o ludziach Wa, tj. Japończykach, którzy, począwszy od małych, skończywszy na starych, tatuują swoje twarze, całe ciała, aby wykazać w ten sposób swoją pozycję społeczną lub aby symbole te chroniły przed złymi duchami, demonami i innymi ciemnymi mocami. Następnie późniejszym już dowodem mogą być zapiski w Nihonshoki, które są z około 720 roku. http://kirei-na-otaku.blog.onet.p1/2010/11/11/irezumi/

${ }^{34}$ Tatuaż jako symbol kary za przewinienia dotrwał mniej więcej do XVII wieku. Każda prefektura, wyspa czy miasto miało swój własny symbol dla zbrodniarzy. W niektórych miejscach symbolem zbrodni był wytatuowany na czole znak kanji inu (pies), a gdzie indziej symbolem takim była tatuowana na lewej ręce powyżej łokcia czarna bransoleta (pas). Był też podwójny pierścień na wysokości bicepsa. W ten sposób właśnie karano zdrajców, dłużników, złodziei, oszustów czy innych przestępców. Tamże 
stępców tatuaże nosili ludzie z różnych warstw społecznych, a wzory na ich ciałach informowały o ich pozycji społecznej.

Najwyższy poziom artystyczny i techniczny tatuaż osiągnął w okresie Edo (XVII-XIX w.) za dynastii Tokugawa i był to złoty wiek tej sztuki - o czym świadczą liczne sztychy, sztuki teatralne i powieści, a tatuowaniem zajmowali się wybitni artyści. Tatuaż japoński posiada wiele wyjątkowych cech niespotykanych w innych rejonach świata, odznaczał się przede wszystkim wielkim bogactwem barw, motywów wiążących się z symboliką życia zawodowego, scenami obrazującymi najważniejsze wydarzenia z życia tatuowanego, upamiętniające bohaterów narodowych, sceny legend i postacie demonów ${ }^{35}$. Ciała mężczyzn i kobiet zdobiono postaciami bogów i ludzi, cytatami z klasyków, scenami ulubionych sztuk teatralnych, kwiatami i ptakami. Wzory wykonywano trzema związanymi razem stalowymi igłami, którymi najpierw robiono rzędy nakłuć, w które wcierano barwny tusz ${ }^{36}$. Tatuaże w Japonii określa się mianem Irezumi lub horimo$n o^{37}$. Na wyspach archipelagu Riukiu do dzisiaj kobiety pokrywają zewnętrzną powierzchnię dłoni charakterystycznym ornamentem (taki tatuaż nazywa się $h a$ $z i c i^{38}$ ), a na wyspie Hokkaido kobiety Ajnów często robiły sobie tatuaż wokół ust, który był oznaką dojrzałości kobiety do zamążpójścia ${ }^{39}$. W połowie XIX w. zwyczaj tatuowania uznano za barbarzyński i zabroniono tej czynności pod groźbą kary. Zakaz ten złagodzono po wizycie w 1881 r. angielskiego króla Edwarda VII, który tak zachwycił się japońskim tatuażem, że kazał sobie wytatuować na ramieniu wielkiego smoka ${ }^{40}$. Obecnie tatuaż w Japonii urósł do rangi sztuki. Tatuatorzy

${ }^{35}$ Lejmann, Tatuaż dawniej i dziś, s. 99.

${ }^{36}$ Mróz, Tatuaż, s. 29

${ }^{37}$ Horimono jest wielobarwny, składa się z pięciu podstawowych kolorów: czerni, czerwieni, zieleni, indygo, żółci, inne kolory powstają z połączenia podstawowych barwników. Kompletny tatuaż japoński pokrywa całe ciało (w tym genitalia) z wyłączeniem twarzy, szyi i dłoni oraz wąskiego pasa skóry tułowia od końca szyi do pępka. Pierwsze horimono rozumiane jako tatuaż artystyczny, zdobiły ciała strażaków z Edo, ich ulubionym motywem był karp i smok, kojarzone z żywiołem wody. Tej grupie zawodowej przypisuje się wylansowanie mody na tatuaże, które szybko zyskały popularność wśród mieszczaństwa (chōnin), do którego zaliczano kupców, rzemieślników i artystów. Każda grupa zawodowa miała inne, zarezerwowane dla siebie motywy, tatuaże odzwierciedlały pozycję społeczną posiadacza. https://pl.wikipedia.org/wiki/Tatua\%C5\%BC_japo\%C5\%84ski (dostęp: 30.03.2017)

${ }^{38}$ Wzory hazici mają kilka symboli takich jak grot (służy jako talizman chroniący przed rozwodem), łuk (oznacza zdrowie dziecka), wachlarz, małże i podobne. Ciekawe jest to, że ornamenty nie były symetryczne na obu rękach. https://ayasugi.wordpress.com/2015/12/04/hazici-tatuaz-okinawskie/ (dostęp: 30.03.2017)

${ }^{39}$ Oprócz symbolizowania gotowości do zawarcia małżeństwa tatuaż służył jako talizman. https://ayasugi.wordpress.com/tag/tatuaz-w-japonii/ (dostęp: 30.03.2017)

${ }^{40}$ Tatuaż japoński przyczynił się do spopularyzowania tej formy zdobienia ciała w Europie, za sprawą angielskiego króla Edwarda VII, który z wizyty w Japonii przywiózł tatuaż z motywem smoka. Informacja została nagłośniona przez prasę i w efekcie tatuaż stał się modny w wyższych sferach w całej Europie, niebawem inni arystokraci stali się posiadaczami podobnych zdobień, m.in.: Jennie Jerome, król Jerzy V, Oskar II Bernadotte - król Szwecji, Haakon VII - król Norwegii, wielcy książęta rosyjscy Aleksy i Konstanty, arcyksiążęta austriaccy Rudolf i Franciszek Ferdynand, królowa 
zaczęli być postrzegani jako artyści. Do tej pory trwałe rysunki na ciele są częścią kultury narodowej tego kraju.

\section{Afryka}

Na kontynencie afrykańskim, oprócz wspomnianego już Egiptu, tatuaż jako zjawisko występuje niezmiernie rzadko ${ }^{41}$. Wyjątkowym zjawiskiem kulturowym jest znajomość tatuażu u plemion Pigmejów ${ }^{42}$. Natomiast potwierdzony został u egipskich Cyganów, gdzie najprawdopodobniej przywędrował wraz z nimi z Azji. Wykonywano go poprzez nakłucia igłą na obu policzkach rozmieszczając koliście, czasami na czole lub niekiedy na wierzchu dłoni. Wśród Cyganek tatuaż miał za zadanie chronić przed ,złym spojrzeniem"43.

W różnych rejonach Afryki spotykany jest najczęściej tatuaż bliznowy. Mężczyźni i kobiety poddają się skaryfikacji na różnych częściach ciała, takich jak plecy, brzuch czy nawet twarz. Na tą dość oryginalną ozdobę decydują się zarówno młode dziewczyny, jak i młodzi chłopcy, którym ma ona pomóc zdobyć serce przyszłych partnerów. Zabieg ten jest bardzo bolesny i może trwać nawet kilka tygodni. Na ciele wycina się głębokie rany, przy czym ważne jest by były to przeróżne, najbardziej skomplikowane wzory. Niekiedy dodatkowo te świeże rany posypuje się substancjami drażniącymi, które powodują, że blizny goją się znacznie wolniej, stają się wypukłe i przez to bardziej widoczne. W plemionach afrykańskich skaryfikacja jest częścią kultury ${ }^{44}$.

\section{Europa}

W cywilizacji starożytnej Grecji i Rzymu tatuaż wynikał z potrzeby identyfikacji społecznej. U Rzymian tatuaże nanoszono skazańcom na twarz lub inną część ciała ${ }^{45}$. Spotykany był również wśród żołnierzy legionów rzymskich (utrwalone na przedramieniu imię Cezara i data wstąpienia do wojska) oraz wśród płatne$\mathrm{rzy}^{46}$. Chociaż Grecy i Rzymianie tatuowanie uważali za działanie barbarzyńskie i szpecenie ciała, to zdarzało się, że niektóre grupy dzięki takim ozdobom podkreślały swoje szlachetne pochodzenie. Oficjalnie istniał zakaz ozdabiania ciała tatuażem przez wolnych obywateli. Najczęściej tatuowano zbiegłych niewolników

Olga i król Jerzy I w Grecji. https://pl.wikipedia.org/wiki/Tatua\%C5\%BC_japo\%C5\%84ski (dostęp: 30.03.2017); Snopek, Tatuaż, s. 25

${ }^{41}$ Na skórze o ciemniej karnacji kolorowy, a zwłaszcza czarny tatuaż jest słabo widoczny.

${ }^{42}$ Nie wiadomo czy tatuaż jest oryginalnym wytworem kultury Pigmejów, czy został przejęty poprzez kontakty od jakiegoś innego ludu znającego ten zwyczaj. Jelski, Tatuaż, s. 22.

${ }^{43}$ Mróz, Tatuaż, s. 30.

$44 \mathrm{https} / /$ urodaizdrowie.pl/co-robia-kobiety-zeby-sie-podobac-mezczyznom-czyli-dziwne-kanony-piekna (dostęp: 30.03.2017)

${ }^{45}$ P. Kubiak, Damnatio ad bestias $i$ inne kary wykonywane na arenie $w$ antycznym Rzymie, Łódź 2014, s. 229.

${ }^{46}$ Jelski, Tatuaż, s. 33-44. 
i przestępców ${ }^{47}$ oraz jeńców ${ }^{48}$. Fakt stosowania tatuażu w obszarze basenu Morza Śródziemnego potwierdzają niektóre starożytne teksty (Dzieje Herodota ${ }^{49}$, Wyprawa Cyrusa (Anabaza) Ksenofonta ${ }^{50}$, Geografia Strabona ${ }^{51}$ ), które informują, że tatuaż pełnił funkcję nie tylko ozdobną, ale i użytkową ${ }^{52}$.

W Europie tatuaż rozpowszechnił się stosukowo niedawno. Za prekursorów należy uznać żeglarzy, którzy wracali z wypraw na Daleki Wschód i do Nowego Świata, dla których takie zdobienie ciała stanowiło pamiątkę z podróży lub służyło im za talizman odstraszający niebezpieczeństwa na morzach i złe moce.

Jak bardzo na terenach Anglii przyjął się zwyczaj tatuowania świadczy fakt, że Harold II (1022-1066), ostatni król z dynastii anglosaskiej miał wytatuowane na piersi imię swojej żony Edith, co pomogło w identyfikacji jego zwłok po przegranej bitwie pod Hastings w 1066 r. ${ }^{53}$ Modzie tatuowania ulegali także przedstawiciele europejskiej arystokracji. Zwłoki francuskiego rycerza d'Aumale'a, który poległ w bitwie pod Saint-Denis w 1591 r., zostały zidentyfikowane dzięki tatuażowi umieszczonemu na jego piersi. Członkowie tajnych organizacji podczas Wielkiej Rewolucji Francuskiej ozdabiali swoje ciała stosownymi politycznymi hasłami. Wśród arystokracji stosowny tatuaż odzwierciedlał karierę wojskową lub był pamiątką z egzotycznych podroży. Car Mikołaj II miał tatuaż, który zrobił sobie podczas pielgrzymki do Jerozolimy, arcyksiążę Franciszek Ferdynand miał wytatuowanego węża ${ }^{54}$.

W XVIII i pierwszej połowie XIX w. tatuaż pełnił funkcje przeważnie identyfikacyjną. Stosowany był np. w szpitalach, w najuboższych warstwach społecznych, przy narodzinach, gdzie dziecku i matce wykonywano na rękach takie same znaki w celu rozpoznania. Wielki rozkwit tatuażu przypadł na okres wojen napoleońskich, kiedy to żołnierze wszystkich walczących armii ozdabiali swoje ciała motywami broni, inicjałami, imionami lub portretami ukochanych kobiet czy da-

${ }^{47} \mathrm{Na}$ czołach zbiegłych niewolników tatuowano lub wypalano napisy: „strzeż się zbiega” (cave a fugitivo), ,pilnuj mnie, ponieważ uciekam i oddaj mojemu panu” (tene me quia fugi et revoca me domino meo), „piętno zbiegów” (epigramma fugitivorum), literę „F”. Szuppe, Tatuaż w prehistorii, starożytności i kulturach plemiennych, s. 2014; http://www.koniecswiata.org/2362/tatuaz-historia-znaczenie-i-jego-rodzaje-starozytna-sztuka-ciala (dostęp: 22.03.2017)

${ }^{48}$ Po pokonaniu Samos w V w. p.n.e. Ateńczycy wytatuowali na czołach pokonanych sowę (symbol miasta), zaś przegranym Ateńczykom i ich sprzymierzeńcom w bitwie pod Syrakuzami w 413 r. p.n.e. zwycięzcy wytatuowali na czołach konia (symbol Syrakuz). Wargacki, Tatuaż, kol. 553.

${ }^{49}$ Herodot z Halikarnasu (ok. 485-425 p.n.e.) podaje w „Dziejach” informację o tym, jak Histiaos z Miletu wysłał swojemu zięciowi Arystagorasowi tajną informację wytatuowaną na głowie niewolnika, który wyruszył w drogę gdy odrosły mu włosy. Snopek, Tatuaż, s. 20.

${ }^{50}$ Ksenofont (ok. 430 - ok. 355 p.n.e.) - grecki pisarz, historyk, żołnierz.

${ }^{51}$ Strabon (ok. 63 r. p.n.e. - ok. 24 r. n.e.) - grecki geograf, historyk i podróżnik.

${ }^{52}$ Snopek, Tatuaż, s. 19-20.

${ }^{53}$ L. Pietrzak, Sztuka wizualna, Poznań 2013, http://leszekpietrzak.com/assets/files/uberink-historia-tatuazu.pdf

${ }^{54}$ Snopek, Tatuaż, s. 24-25. 
tami zwycięskich bitew ${ }^{55}$. Pod koniec XIX i w pierwszym dziesięcioleciu XX w. w cyrkach, jarmarkach, ludowych festynach i przeróżnych gabinetach osobliwości, najczęściej w celach zarobkowych, występowali ludzie obficie wytatuowani. Zjawisko to było szczególnie popularne wśród słabo rozwiniętych kulturalnie warstw społeczeństwa, ale też stało się niezwykle modne w sferach towarzyskich, szczególnie w Anglii i to najbardziej wśród kobiet ${ }^{56}$. Dość szybko rozpowszechniło się w środowiskach przestępczych, wśród osadzonych i kryminalistów. Spełniało funkcje komunikacji i identyfikacji, każdy tatuaż w świecie przestępczym miał znaczenie i niósł konkretny przekaz ${ }^{57}$. Na tatuaż składały się różne znaki graficzne oraz ich kombinacje: kropki, litery, cyfry, proste rysunki. Wyrażały rodzaj przestępstw, szczególne umiejętności, miejsce w hierarchii, cechy osobowościowe, poglądy polityczne, preferencje seksualne i inne ${ }^{58}$.

Tatuaż przeżywał swój ponowny renesans $\mathrm{w}$ drugiej połowie lat 60 . i początku 70. XX w. w Stanach Zjednoczonych i Europie, a związane było to z młodzieżową kontrkulturą kontestacyjną hipisów. Dzisiaj to modny w szerokich kręgach osobisty ornament, element popkultury.

\section{Aspekt religijny}

Najstarsze pisane świadectwa odnoszące się do tatuażu znaleźć można w Piśmie Świętym. W Starym Testamencie w Księdze Kapłańskiej (Kpł 19,2859) i Księdze Powtórzonego Prawa (Pwt 14,160) zakazuje się stosowania tatuażu jako wyrazu żałoby. Pierwsi chrześcijanie, w czasach prześladowań, zdobili swoje ciała, tatuując na czole lub nadgarstku znaki swojej wiary. Były to chrześcijańskie symbole: baranek, ryba, krzyż oraz monogramy związane z imieniem Chrystusa $\mathrm{X}, \mathrm{XP}^{61}$. Stanowiły one akt zjednoczenia i przynależności do wspólnoty, o czym

${ }^{55} \mathrm{~W}$ drugiej połowie XIX w. w wojsku francuskim tatuowanie zostało zabronione ze względów higienicznych, gdyż powodowało rozprzestrzenianie się wielu groźnych chorób, w tym wenerycznych. Snopek, Tatuaż, s. 24.

${ }^{56}$ Mania tatuowania, która szczególnie ogarnęła młode dziewczęta i kobiety w Anglii po pierwszej wojnie światowej, doprowadziła do wydania w 1922 przez rząd zakazu tatuowania kobiet poniżej 21 roku życia. Lejmann, Tatuaż dawniej i dziś, s. 100.

${ }^{57}$ Tatuaże przestępczego półświatka można z grubsza podzielić na dwie grupy. Pierwsza dotyczy gangów i innych zorganizowanych grup przestępczych jak np. mafie czy gangi. Druga grupa tatuaży, to „dziary” wykonywane na tych przestępcach, którzy dali się złapać. Wykonywano go najczęściej prymitywnymi narzędziami (spinacze, szpilki, druty, żyletki, kawałki szkła) i środkami chemicznymi, często niebezpiecznymi dla zdrowia. Używano takich barwników jak sproszkowany węgiel, proch strzelniczy, sadza, farby, indygo, ultramaryna, kurkuma, henna, kwas siarkowy czy błękit pruski. http://www.gram.pl/artykul/2010/06/29/all-points-bulletin-tatuaze-przestepcow.shtml (dostęp: 30.03.2017)

${ }^{58} \mathrm{http} / / / w w w . n e w s w e e k . p l / p o l s k a / t a j e m n y-k o d-t a t u a z y, 61949,1,1 . h t m l$ (dostęp: 31.03.2017)

${ }^{59}$ Nie będziecie nacinać ciała na znak żałoby po zmarłym. Nie będziecie się tatuować. Ja jestem Pan! 35. Pismo święte Starego i Nowego Testamentu, Poznań 2016, s. 143.

${ }^{60}$ „Wy jesteście dziećmi Pana, Boga waszego. Po zmarłym nie będziecie nacinać sobie skóry ani strzyc krótko włosów nad czołem". Pismo Święte, s. 213-214.

${ }^{61}$ Fakt ten potwierdza Prokop z Gazy, który pisał, że wielu wczesnych chrześcijan kazało sobie utrwalać na dłoniach i ramionach znak krzyża, imię Chrystusa, monogram XP lub znak T na czole 
czytamy w Nowym Testamencie, w Liście św. Pawła skierowanym do Galatów (Ga 6,1762). Wykonanie trwałych rysunków w formie znaków lub „pieczęci Boga na czołach" odnajdujemy w Apokalipsie św. Jana (Ap 7,3-4; 9,4; 13,16; 14,1; 20,$\left.4 ; 22,4^{63}\right)$.

Do dnia dzisiejszego zdarza się w Kościele etiopskim, że wierni noszą na czole wytatuowane krzyże lub znaki związane z imieniem Chrystusa, a w Kościele koptyjskim w czasie chrztu na rączkach dziecka tatuuje się mały krzyż ${ }^{64}$.

W 330 r. cesarz Konstantyn Wielki ${ }^{65}$, pierwszy chrześcijański cesarz rzymski, zakazał tatuowania twarzy by nie szpecić tego, co zostało stworzone na podobieństwo Boga ${ }^{66}$. Około 600 r. Izydor, biskup Sewilli67 po raz pierwszy dość dokładnie opisał tatuaż. W jednym ze swoich dzieł przytoczył zwyczaj ozdabiania ciał u Piktów ${ }^{68}$. W 787 r. w Calcuith w hrabstwie Northumberland ${ }^{69}$ odbył się synod, na którym legat papieski w imieniu papieża Hadriana I wprowadził całkowity zakaz tatuowania ciała ${ }^{70}$. Wprowadzenie tego zakazu pokazuje, jak w okresie średniowiecza dochodziło do wzajemnego przenikania motywów pomiędzy tatuażem stosowanym przez wspólnoty chrześcijańskie, a tatuażem używanym przez plemiona pogańskie. Zwyczaj tatuowania praktykowali także rycerze w czasach wy-

mający wyobrażać krzyż. Prokop z Gazy - filozof bizantyński, mistrz szkoły retorycznej w Gazie, zwany „,chrześcijańskim sofistą”. Jelski, Tatuaż, s. 45.

${ }^{62}$ Odtąd niech już nikt nie sprawia mi przykrości: przecież ja na ciele swoim noszę blizny, znamię przynależności do Jezusa. Pismo Święte, s. 1539.

${ }^{63}$ Pismo Święte, s.1632-1647; Wargacki, Tatuaż, kol. 553.

${ }^{64}$ Zwoliński, Mowa ciała, s. 42.

${ }^{65}$ Konstantyn Wielki był zwierzchnikiem wszystkich kultów religijnych Cesarstwa Rzymskiego, a chrześcijaństwo było w roku 325 religią tolerowaną. https://pl.wikipedia.org/wiki/Sob\%C3\%B3r_ nicejski_I (dostęp: 30.03.2017)

${ }^{66}$ Zwliński, Mowa ciała, s. 42.

${ }^{67}$ Izydor z Sewilli, również Izydor Sywilski, łac. Isidorus Hispalensis (ur. ok. 560-636) - arcybiskup Sewilli, święty Kościoła katolickiego, doktor Kościoła.

${ }^{68}$ „Piktowie mieli zgodny ze swoim imieniem obyczaj ozdabiania ciała obrazkami. Zniekształcali oni ciało, nakłuwając igłami skórę i wcierając w nią sok pewnych roślin”. Jelski, Tatuaż, s. 46; Piktowie (łac. picti - ,pomalowani”, ze względu na ciała pokryte tatuażami) byli ludem zamieszkującym obszar obecnej Szkocji. https://pl.wikipedia.org/wiki/Piktowie (dostęp: 30.03.2017)

${ }^{69}$ Osulf being king, Pope Adrian sent Gregory bishop of Ostia, and Theophilact bishop of Todi, as legates to assist at the synod of Calcuith, as Sir Henry Spelman says, A. D. 787. One of the legates travelled into the kingdom of Northumberland, and was present at a meeting of all the great men of that territory, both clergy and laity, when certain orders were agreed to for the discipline and reformation of manners. Robert Surtees, The history and antiquities of the County Palatine of Durham, Sunderland 1908, t. 1, s. 52 https://books.google.pl/books?pg=PA52\&lpg=PA51\&dq=Northumberland $+787+$ synod\&id=O5AxAQAAMAAJ\&hl=pl\&ots=D_8egBRVnP\&output=text

${ }^{70}$ All Heathenish customs are to be abolished; particularly, the people are forbidden to deform their bodies by any superstious marks or scars, after the Pagan manmer. These canons were first read in the Northumbrian synod, where, after they had been subscribed to by the king, the bishops, temporal nobility, and inferior clergy of province, they were brought by the legates to the synod of Calcuith, and there ratified by the king, the archbishop of Canterbury, and all parties present. Tamże. 
praw krzyżowych, którzy na ramionach, piersiach i rękach tatuowali znak krzyża. Znak ten w razie śmierci na polu walki miał zapewnić chrześcijański pochówek ${ }^{71}$.

W krótkim czasie praktykę tatuowania przejęli również chrześcijańscy pątnicy odbywający pielgrzymki do Ziemi Świętej. Nie tylko po to, by podkreślić swoją religijną tożsamość, ale przede wszystkim jako dowód przebytej podróży, jako niezmywalnego świadectwa prawdziwej i jedynej wiary 72 .

Pod koniec średniowiecza tatuaż był dość rozpowszechniony szczególnie wśród najniższych warstw społecznych. Władze kościelne mocno i stanowczo potępiały ten zwyczaj i ostrzegały wiernych przed jego stosowaniem. Wyjątkiem była chrześcijańska ludność Bośni i Hercegowiny, gdzie ze względu na częste najazdy wojsk Imperium Osmańskiego, rada katolicka zezwoliła ludności na tatuowanie sobie krzyży, jako sposobu zabezpieczenia się przed przechodzeniem na islam ${ }^{73}$. Obyczaj tatuowania uprawiany był głównie przez kobiety.

Dziewczęta w okresie dojrzewania poddawane były temu zabiegowi 19 marca, w dzień św. Józefa (wigilię wiosennego przesilenia słońca) ${ }^{74}$. Tatuażami pokrywano zwykle zewnętrzne części rąk, zaczynając od dłoni, a kończąc na okolicy łokcia, czasem ozdabiana jest także górna część piersi, a u mężczyzn (rzadko) zewnętrzna część ramienia. Najczęściej używanymi motywami były bardzo ozdobnie potraktowane: gwiazda, koło, krzyż, księżyc, słońce, jodełki i kłosy ${ }^{75}$.

\section{Zakończenie}

Podsumowując należy stwierdzić, że tatuaż występował praktycznie na wszystkich kontynentach jako tabu czy oznaka powiązań przestępczych, choć wiele młodzieżowych gangów nadal stosuje tę formę potwierdzenia lojalności ${ }^{76}$. Proces rozpoczęty wynalezieniem elektrycznej maszynki do tatuowania ${ }^{77}$ doprowadził do tego, że tatuaż stał się dostępny szerokim masom. Pojawił się na świecie pewien snobizm na posiadanie dyskretnych tatuaży (np. w miejscach intymnych) oraz powstała kategoria tatuażu artystycznego (sławni projektanci, ekskluzywne

${ }^{71}$ Jelski, Tatuaż, s. 44-45.

${ }^{72}$ Snopek, Tatuaż, s. 21.

${ }^{73}$ Zwyczaj tatuowania krzyży sięga XV w., miał chronić chorwackich katolików przed tureckimi prześladowaniami. Pietrzak, Sztuka wizualna, http://leszekpietrzak.com/assets/files/uberink-historia-tatuazu.pdf

${ }^{74}$ Kult ów wygasł, gdy w komunistycznej Jugosławii po II wojnie światowej, religia została wyeliminowana z życia publicznego. https://www.vice.com/pl/article/kult-tatuazu-wsrod-chorwackich-babek (dostęp: 30.03.2017)

${ }^{75}$ K. Moszyński, Kultura ludowa Stowian: Kultura duchowa, t. 2, wyd. 2, Warszawa 1968, s. $51-53$.

${ }^{76}$ Zwoliński, Mowa ciała, s. 43-44.

${ }^{77}$ Nieudany wynalazek Thomasa Edisona - elektryczne pióro kopiujące, miało pomagać w kopiowaniu dokumentów. Podczas pisania igła pozostawiała za sobą ślad złożony z małych dziurek; potem tak perforowaną powierzchnie wystarczyło przejechać wałkiem nasączonym farbą. W roku 1891 w USA Samuel O'Reilly zastosował tę technologię do mechanicznego nanoszenia tatuażu według przygotowanych szablonów. http://ciekawe.onet.pl/nieprzecietni/zapomniane-wynalazki-edisona-10-rzeczy-o-ktorych-n,1,5606294,artykul.html (dostep: 09.05.2017) 
i drogie pracownie - „studia tatuażu”). A dostęp do masowych środków przekazu i różnych technologii dał temu zjawisku nieograniczony zasięg. Wymieszaniu i uśrednieniu uległa także ikonografia tatuażu.

W kulturze zachodniej tatuaż zaczyna być postrzegany jako rodzaj sztuki, która dość szybko wkracza do życia społecznego ${ }^{78}$. Świadczą o tym choćby od kilkunastu lat powstające muzea tatuażu w Europie: The Amsterdam Tattoo Museum, The British Tattoo History Museum, w obu Amerykach - Tattoo Museum Buenos Aires, The Baltimore Tattoo Museum, Tattoo Art Museum of San Francisco, w Azji Tokyo Tattoo Museum i The Museum of New Zealand Te Papa Tongarewa, a nawet w Polsce - Muzeum Tatuażu w Gliwicach ${ }^{79}$. W muzeach można zapoznać się z historią tatuażu, zobaczyć dawne i współczesne narzędzia, barwniki, wzory, poznać nazwiska najsłynniejszych tatuatorów, unikatowe egzemplarze fachowej literatury, a przede wszystkim malarskie, graficzne, drzeworytnicze i fotograficzne przedstawienia wytatuowanych kobiet i mężczyzn, a często także szczegóły zdobiących ich ciała skomplikowanych kompozycji.

Współcześnie tatuaż jest symbolem niezależności, indywidualności, osobistym środkiem wyrazu odróżniającym od innych ludzi. Zdecydowanie zmieniło się na lepsze przyzwolenie dla tych, którzy ozdabiają swoje ciała. Tatuaż może być również stosowany z potrzeb estetycznych, może zakrywać różne wady (skazy niedoskonałości) skóry lub blizny po wypadkach.

Słowa kluczowe: tatuaż; historia tatuażu; zjawisko tatuażu; tatuowanie; techniki tatuowania; dekorowanie ciała

\section{BIBLIOGRAFIA}

\section{Opracowania}

[bez tyt.], ,Światowid Ilustrowany Kurjer Tygodniowy”, 3 (1926) nr 37, s. 9.

Delio Michelle, Tatuaż, Warszawa 1995.

Jelski Andrzej, Tatuaż, Warszawa 1993.

Kubiak Przemysław, Damnatio ad bestias i inne kary wykonywane na arenie w antycznym Rzymie, WUŁ, Łódź 2014.

Kukuczka Jacek, Afrykańskie tatuaże bliznowe, „Ludzie i Kultury”, 1 (2003) s. 33-43.

Lejman Kazimierz, Tatuaż dawniej i dziś, jako zagadnienie obyczajowe, psychologiczne i lekarskie, ,Archiwum Historii medycyny”, 29 (1966) s. 95-118.

Moszyński Kazimierz, Kultura ludowa Słowian: Kultura duchowa, t. 2, wyd. 2, Warszawa 1968.

${ }^{78}$ W Tajlandii w świątyni Wat Bang Phra, położonej w miejscowości Nakhon Chaisi niedaleko Bangkoku, każdego roku odbywa się Festiwal Magicznego Tatuażu. M. Borowik, Sztuka na skórze pisana, http://www.sukcesmagazyn.pl/artykul/1102876.html (dostęp: 30.03.2017)

${ }^{79}$ Muzeum Tatuażu w Gliwicach powstało 30 czerwca 2012 r. Jest to jedyna tego typu inicjatywa w środkowo-wschodniej Europie http://www.tattoomuseum.pl/index.php/homepage (dostęp: 30.03.2017) 
Mróz Lech, Tatuaż, „Poznaj Świat”, 1969, s. 27-30

Nowak Robert, Psychologiczne aspekty tatuowania się, „Roczniki Psychologiczne”, 15 (2012) nr 2, s. 87-104.

Pismo Święte Starego i Nowego Testamentu, Biblia Tysiąclecia, Poznań 2016.

Russ Thorn, Sztuka tatuażu: inspiracje, style i techniki wielkich współczesnych mistrzów tatuażu, Warszawa 2014.

Skopek Mariusz, Tatuaż: element współczesnej kultury, Toruń 2013.

Szuppe Paweł, Tatuaż w prehistorii, starożytności i kulturach plemiennych, „Nurt SVD”, 43 (2009) z. 2, s. 197-210.

Wargacki Stanisław, Tatuaż, w: Encyklopedia Katolicka, t. 19, Lublin 2013, kol. 552-553.

Wołoszyn Janusz, Skartfikacja, tatuaż i malowanie twarzy w kulturze Moche - propozycja typologii dla „naczyń portretowych”, „Światowit”, 4 (2002) nr 4, s. 219-227.

Zwoliński Andrzej, Mowa ciała, Kraków 2006.

\section{Netografia}

Borowik Michał, Sztuka na skórze pisana http://www.sukcesmagazyn.pl/artykul/1102876. html

http://ciekawe.onet.pl/nieprzecietni/zapomniane-wynalazki-edisona-10-rzeczy-o-ktorych-n, 1,5606294, artykul.html

http://i.huffpost.com/gadgets/slideshows/228308/slide_228308_1012873_free.jpg

http://kirei-na-otaku.blog.onet.pl/2010/11/11/irezumi/

http://renatazarzycka.pl/2011/04/tatuaz-dobry-czy-zly-obyczaj/

http://www.ancient.eu/article/1000/

http:/www.gram.pl/artykul/2010/06/29/all-points-bulletin-tatuaze-przestepcow.shtml

http://www.koniecswiata.org/2362/tatuaz-historia-znaczenie-i-jego-rodzaje-starozytna-

-sztuka-ciala

http://www.newsweek.pl/polska/tajemny-kod-tatuazy,61949,1,1.html

http://www.teara.govt.nz/en/photograph/31565/caren-fox

http://zblogowani.pl/wpis/9237924/jak-powstaje-tatuaz

https://ayasugi.wordpress.com/2015/12/04/hazici-tatuaz-okinawskie/

https://ayasugi.wordpress.com/tag/tatuaz-w-japonii/

https://pl.pinterest.com/Mollyloucracked/vintage-tattoo/?lp=true

https://pl.wikipedia.org/wiki/\%C3\%96tzi

https://pl.wikipedia.org/wiki/Moko

https://pl.wikipedia.org/wiki/Piktowie

https://pl.wikipedia.org/wiki/Tatua\%C5\%BC_japo\%C5\%84ski

https://urodaizdrowie.pl/co-robia-kobiety-zeby-sie-podobac-mezczyznom-czyli-dziwne-

-kanony-piekna

https://www.vice.com/pl/article/kult-tatuazu-wsrod-chorwackich-babek

Pietrzak Leszek, Tatuaż jako sztuka wizualna-Tattoo as visual art-Tattoo als visuelle Kunst, Poznań 2013 http://leszekpietrzak.com/assets/files/uberink-historia-tatuazu.pdf

Raport końcowy, Modyfikacja tatuaże, Łódź 2011, s. 3. http://www.eksoc.uni.lodz.pl/is/ doc/tatoo.pdf

Surtees Robert, The history and antiquities of the County Palatine of Durham, Sunderland 1908, t. 1 https://books.google.pl/books?pg=PA52\&lpg=PA51\&dq=Northumberlan$\mathrm{d}+787+$ synod\&id=O5AxAQAAMAAJ\&hl=pl\&ots=D_8egBRVnP\&output=text 


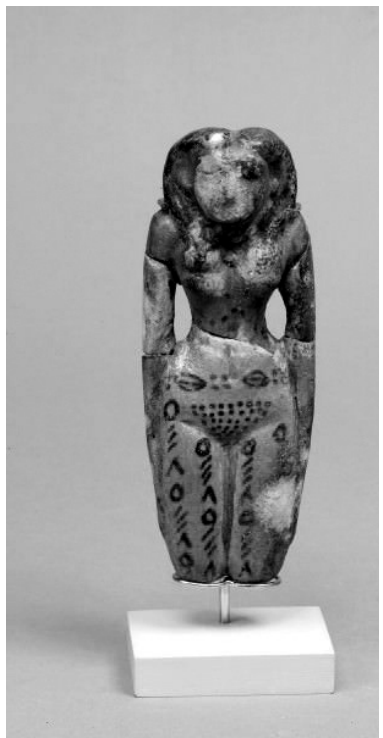

Egipska figurka (1850-1640 p.n.e.).

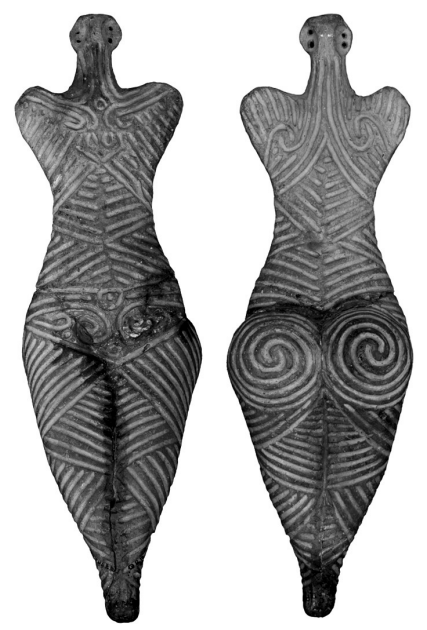

Rumunia figurki $\mathrm{V}$ wiek p.n.e.

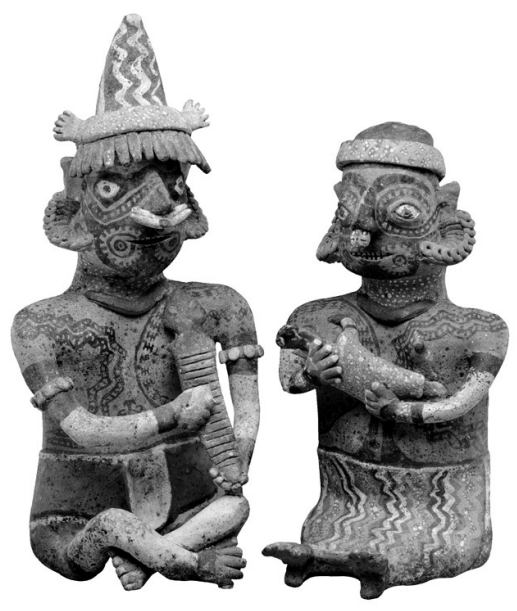

Meksyk figurki 100 p.n.e. - 400 n.e. 


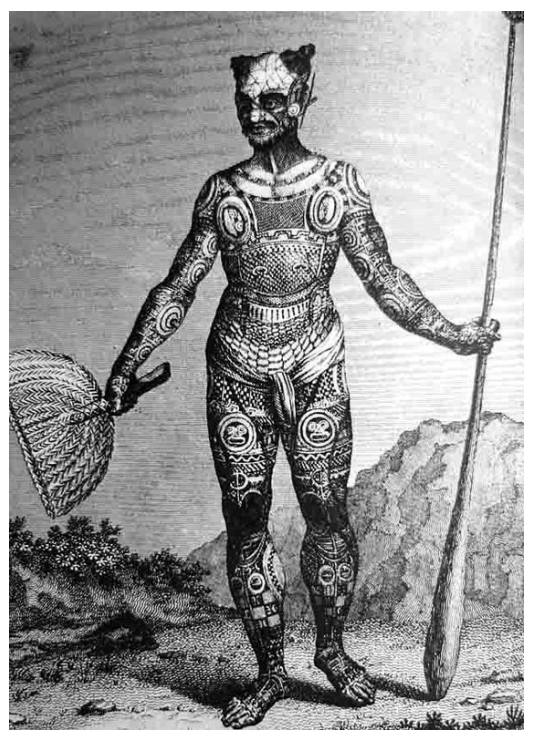

Mężczyzna z Markizów.

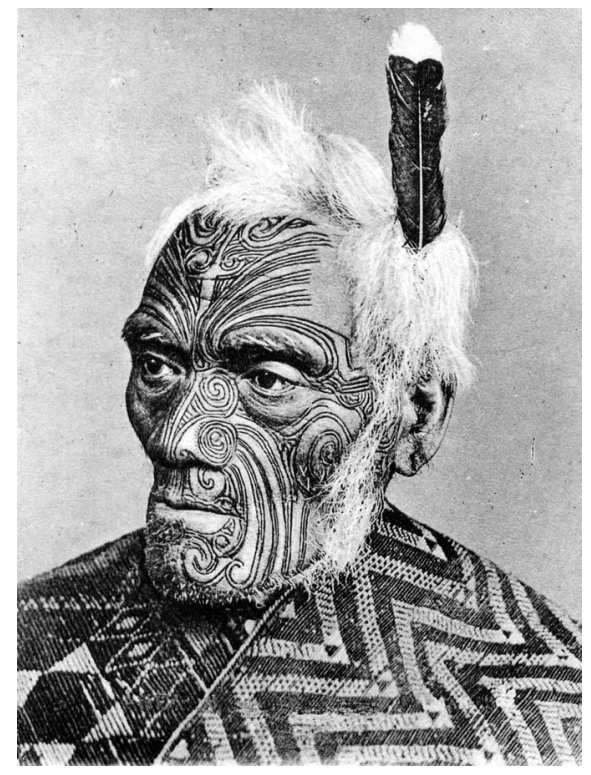

Tatuaż moko. 


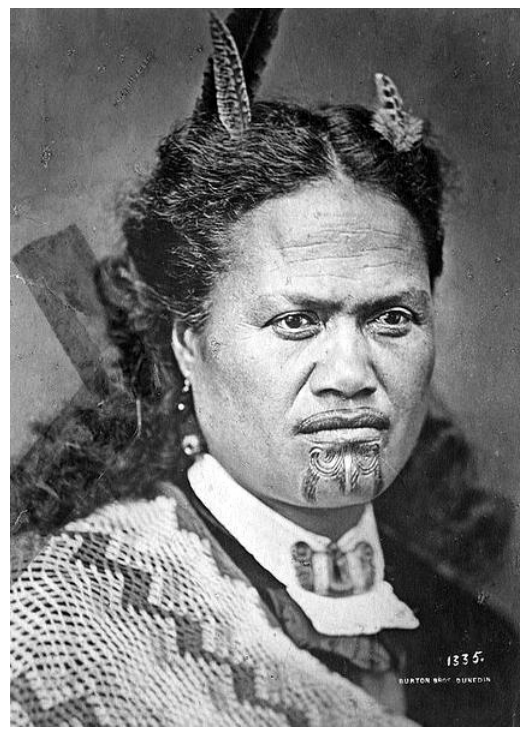

Maoryska z tatuażem na brodzie.

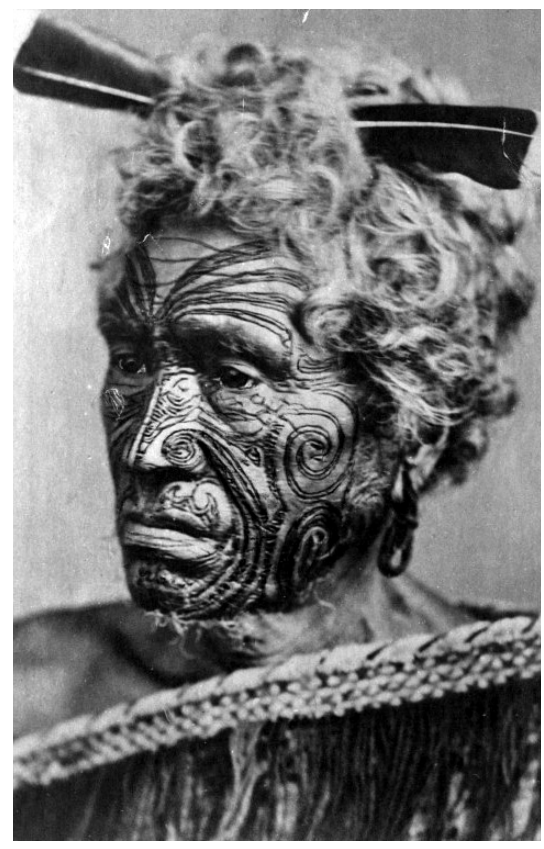

Maorys z tatuażem na twarzy. 


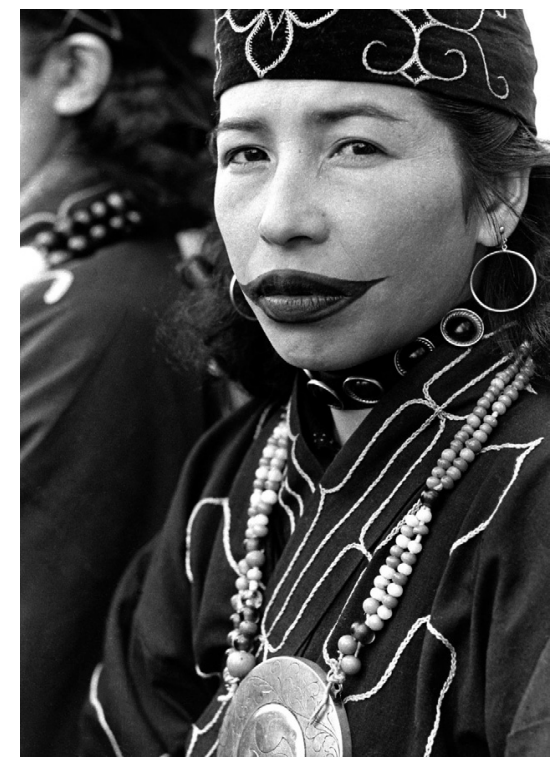

Kobieta Ajnu.

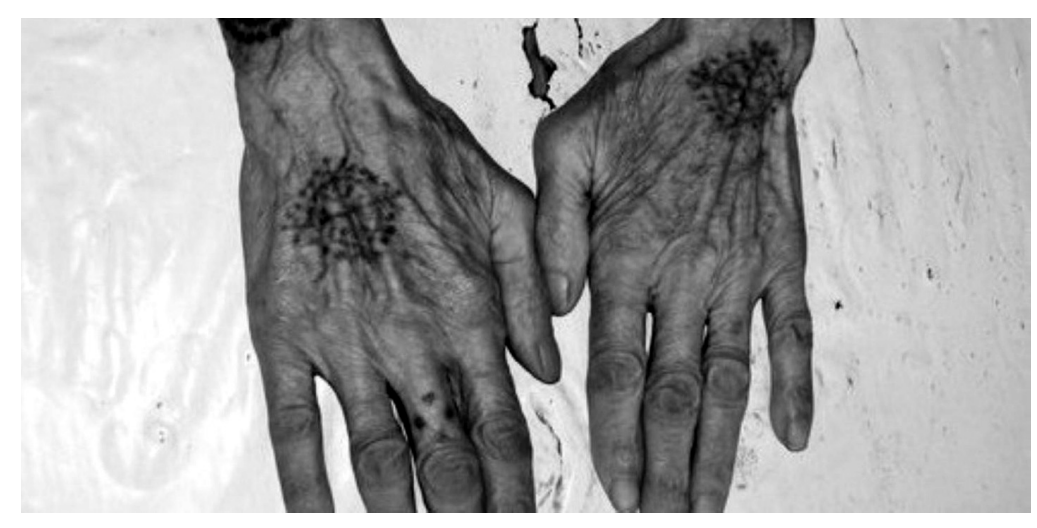

Dłonie kobiety z Bośni. 


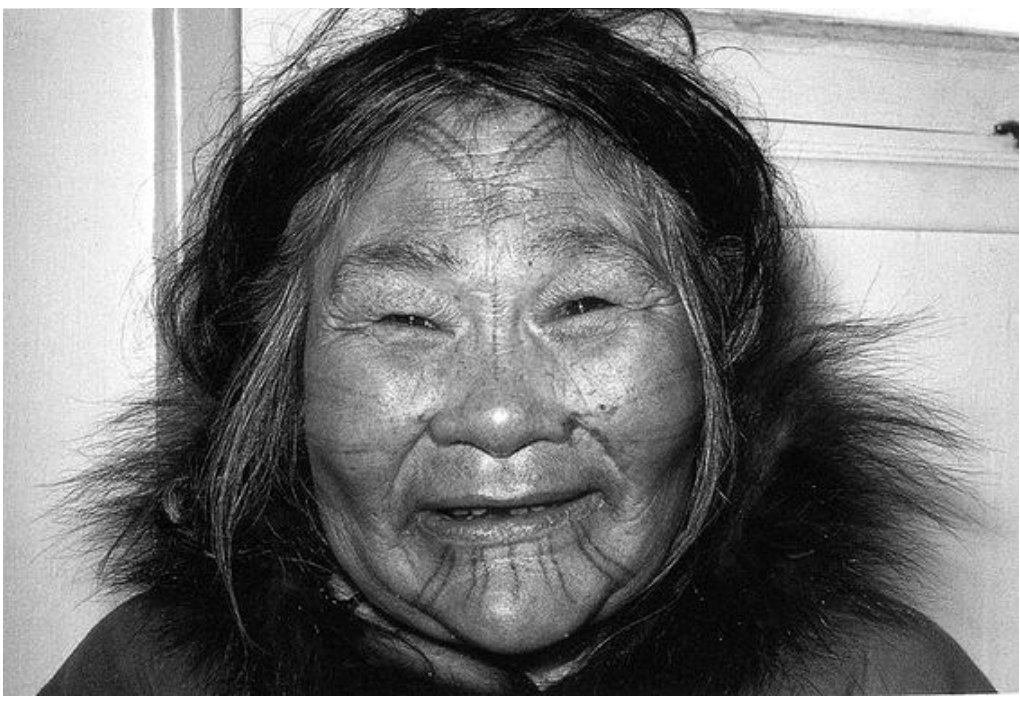

Eskimoska.

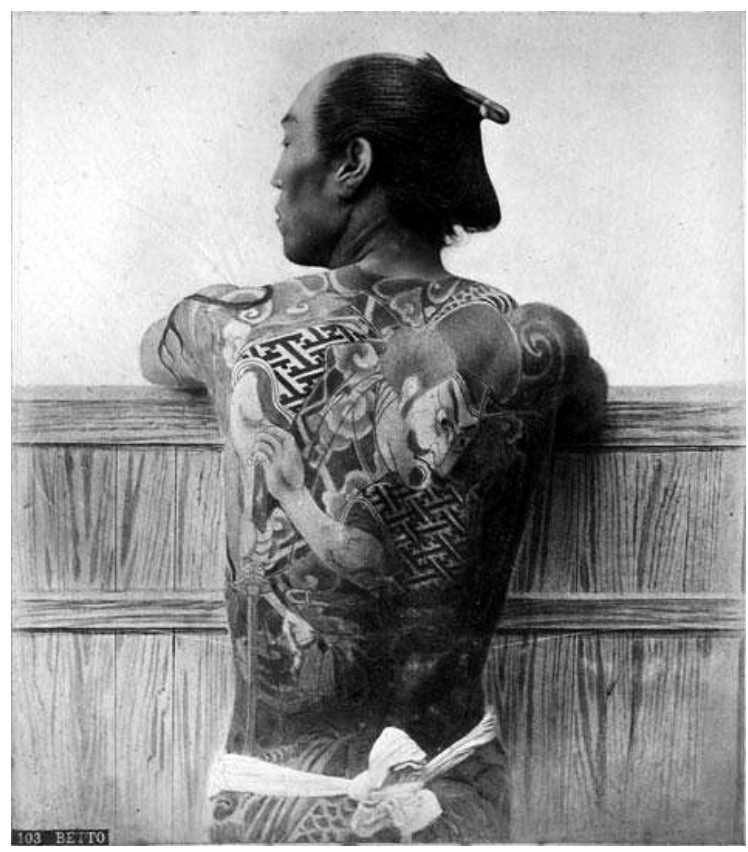

Japoński tatuaż irezumi. 


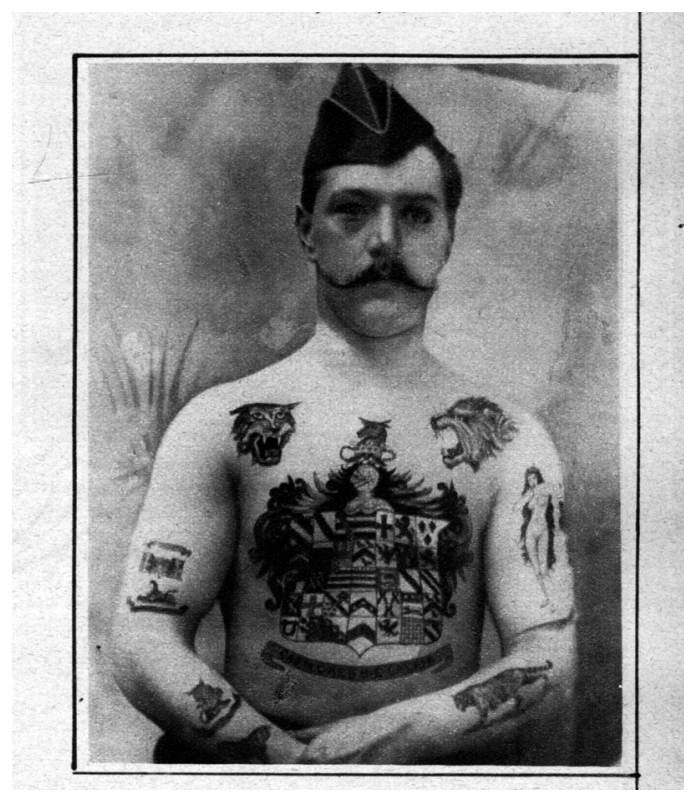

Wytatuowany oficer angielski, $1889 \mathrm{r}$.

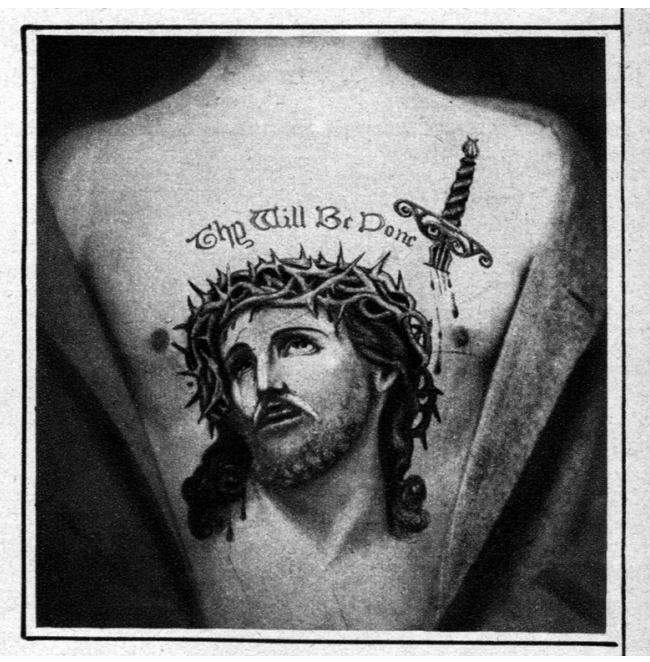

Tatuaż na piersiach mężczyzny, $1889 \mathrm{r}$. 


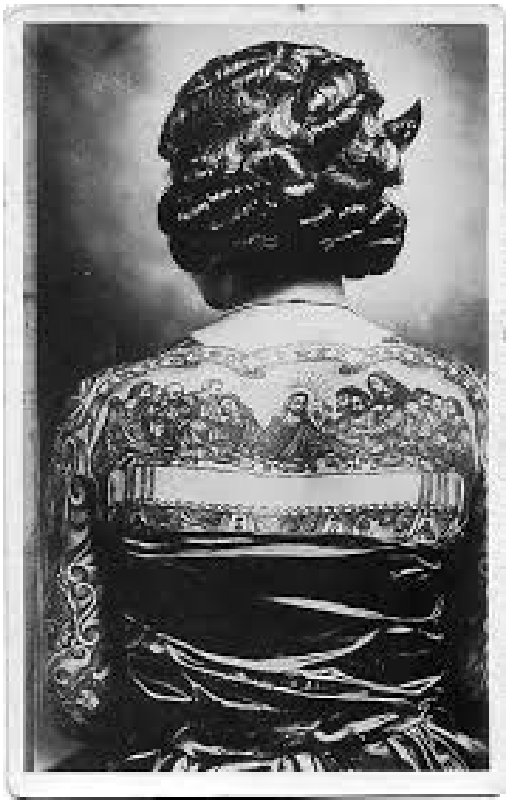

Tatuaż na plecach kobiety, 1920 r.

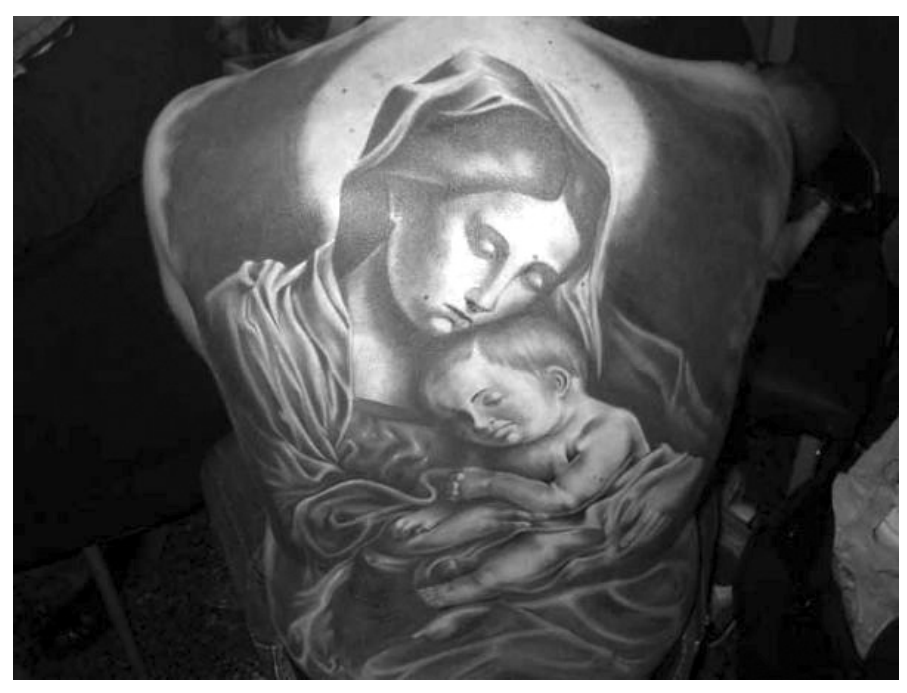

Tatuaż współczesny. 


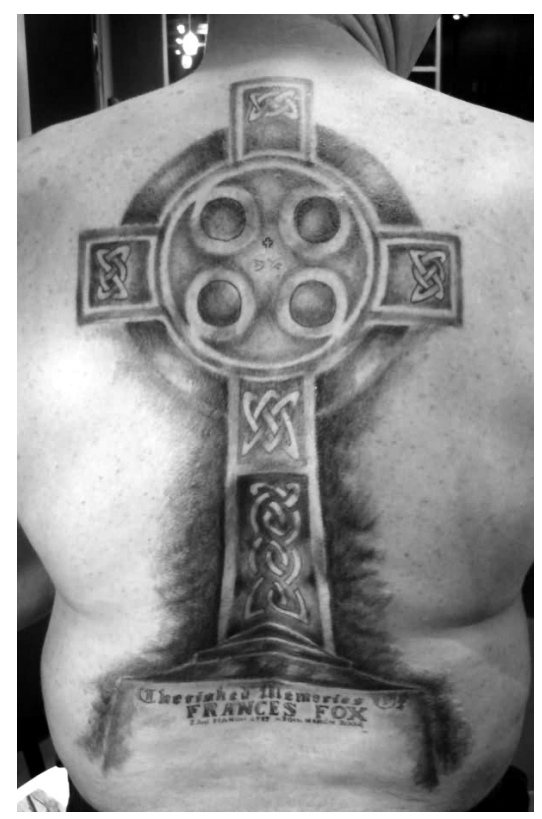

Tatuaż współczesny.

\section{A TATTOO AS A SIGN OF BELONGING TO A PARTICULAR GROUP}

\section{Summary}

A tattoo is the oldest form of visual individualization, occurring since the dawn of history. Initially, tattoos had protective and ritualistic functions. They differed in respect of social status and religious affiliation. People believed in their curative and magical power. There have been different tattoo techniques depending on the geographic location, material and tools, time, civilization development and tradition. Today's tattoos are mainly used to decorate the body, but still some people have tattoos done as they are willing to emphasize their belonging to the social group, to commemorate important life events or they are guided by other personal motivations.

Keywords: a tattoo, the history of tattoos, the tattoo phenomenon, tattooing, tattoo techniques 